\title{
Survival in a patient with severe paraneoplastic hyponatremia: a
}

\section{case report}

\author{
Gary V Walker ${ }^{1}$ and Michael C Peterson*2
}

Address: ${ }^{1 B C M}$-Michael Debakey Center, Room M220, One Baylor Plaza, Houston, TX 77030, USA and 2Division of General Internal Medicine, University of Utah SOM, Salt Lake City, UT 84648 and Cardiac Hospitalist Service, Central Utah Clinic, Provo, UT 84604, USA

Email: Gary V Walker - gvwalker@bcm.edu; Michael C Peterson* - michael.peterson@hsc.utah.edu

* Corresponding author

Published: 17 October 2008

Cases Journal 2008, I:248 doi:10.1 I86/1757-1626-1-248

This article is available from: http://www.casesjournal.com/content/l/I/248

(C) 2008 Walker and Peterson; licensee BioMed Central Ltd.

This is an Open Access article distributed under the terms of the Creative Commons Attribution License (http://creativecommons.org/licenses/by/2.0), which permits unrestricted use, distribution, and reproduction in any medium, provided the original work is properly cited.

\begin{abstract}
Background: Hyponatremia is a common and potentially life threatening problem in patients with neuroendocrine tumors.

Case presentation: A 54-year-old female with a history of smoking and narcotic dependency presented to her primary care physician with nausea, vomiting, fatigue, malaise, ataxia and a serum sodium of $100 \mathrm{mEq} / \mathrm{L}$. A chest computerized tomography $(\mathrm{CT})$ revealed a $4.1 \times 4.9 \mathrm{~cm}$ precarinal/ pretracheal mass encircling the right brachiocephalic vein. A mediastinal biopsy found a malignant, intermediate-size small cell (oat cell) carcinoma. Saline infusion along with intravenous furosemide successfully corrected her hyponatremia. Unfortunately, the patient later died of complications related to her cancer and cancer therapy.
\end{abstract}

Conclusion: Paraneoplastic hyponatremia can be severe, but even severe cases may be successfully treated.

\section{Introduction}

Hyponatremia is a common clinical problem that when symptomatic may manifest with nausea, disorientation, seizures, coma, cerebral edema and even death [1]. It is evident in approximately $15 \%$ of patients with small-cell lung cancer [2]. The etiology of hyponatremia in smallcell carcinoma has been attributed most often to high levels of vasopressin (AVP); however, atrial natriuetic peptide (ANP) has been implicated as well $[3,4]$. Correction of hyponatremia is usually successful at moderately low sodium levels, although it must be done slowly to prevent irreversible osmotic demylination. It has been shown that correction is more likely to be successful in persons with higher sodium levels and that death is more likely for persons with more severe hyponatremia [5].
We report a case of very severe hyponatremia related to a neuroendocrine tumor where the patient's sodium was successfully corrected.

\section{Case presentation}

A 54-year-old white female presented to her primary care physician with a four-day history of nausea, vomiting, fatigue, malaise, blurry vision and difficulty walking. She reported a subjective weight loss over the previous month. She had a previous history of major depressive disorder with anxiety, chronic back pain, alcohol dependence in partial remission, 70 pack year smoking history, alcohol withdrawal seizures, hypertension, herniated nucleus pulposus of cervical, thoracic and lumbar spine, cerebrovascular accident at 35 years of age and narcotic dependence. 
Her past surgical history revealed bilateral mastectomy for fibrocystic disease with reconstructive surgery, total knee replacement, bilateral cataract surgeries, right knee arthroscopy with meniscus repair, appendectomy, tonsillectomy, cervical and lumber spine fusion, as well as vaginal hysterectomy with bilateral salpingo-oopherectomy for non-cancerous reasons at age 36. Her father died of myocardial infarction at age 52, brother died of myocardial infarction and her mother with Paget's disease of the breast. She reported having three sons with two living. Her medications include amlodipine, oxycodone, oxycodone and acetaminophen, diazepam, metoprolol succinate, and aspirin. She reported taking these medicines as prescribed.

One month previously, a blood test showed a serum sodium of $121 \mathrm{mEq} / \mathrm{L}$. The patient left the doctor's office against medical advice, receiving no recommendations for evaluation or therapy. When she returned later with the same symptoms, her serum sodium level was $100 \mathrm{mEq} / \mathrm{L}$. The patient displayed slowed speech and some difficulty with balance and gait. Potassium and creatinine levels were within normal limits. She denied excessive water ingestion or diuretic use. The patient had no evidence of hypothyroidism, heart failure or adrenal insufficiency. Urine osmolality was 413 and serum osmolality was 213 . A chest CT showed a $4.1 \times 4.9 \mathrm{~cm}$ precarinal/pretracheal mass encircling the right brachiocephalic vein.

The patient was treated with gentle saline infusion and low doses of intravenous furosemide with frequent monitoring of electrolytes. Her treatment was later amended to fluid restriction after her sodium rose. On successive days her serum sodium was $113 \mathrm{mEq} / \mathrm{L}, 125 \mathrm{mEq} / \mathrm{L}$ and 132 $\mathrm{mEq} / \mathrm{L}$ respectively and it was noted that the patient's neurologic symptoms quickly resolved. The patient was discharged on the fifth day with a serum sodium of $133 \mathrm{mEq} /$ $\mathrm{L}$ and instructed to restrict free water intake to $900 \mathrm{cc} /$ day. A biopsy at mediastinoscopy revealed a malignant, intermediate-size small cell (oat cell) carcinoma. Radiation and chemotherapy was initiated. Later, the patient unfortunately died from complications related to her cancer and therapy.

The causes of hyponatremia vary widely, from pharmacological to physiological factors. Neuroendocrine tumors may cause hyponatremia. Narcotics have also been implicated as a cause of hyponatremia; one patient recovered from a narcotic-induced hyponatremia of $108 \mathrm{mEq} / \mathrm{L}$ [6]. We believe that hyponatremia in this patient was a result of her neuroendocrine tumor perhaps augmented by her use of narcotics.

Serum sodium levels of $100 \mathrm{mEq} / \mathrm{L}$ or lower are extremely rare in the literature. One schizophrenic patient with polydipsia died with a serum sodium of $92 \mathrm{mEq} / \mathrm{L}$ [7]. Survival has been reported in patients whose serum sodium levels were $86 \mathrm{mEq} / \mathrm{L}$ [8], $101 \mathrm{mEq} / \mathrm{L}$ [5] and 103 $\mathrm{mEq} / \mathrm{L}[9]$.

\section{Conclusion}

In general, correction of hyponatremia should be done slowly to avoid osmotic demyelination. However, more rapid correction may be warranted in symptomatic patients, for example those with seizure or coma. For treating severe, symptomatic hyponatremia, infusion of hypertonic saline or saline combined with furosemide, with frequent monitoring of sodium levels, has been recommended. Asymptomatic or mild hyponatremia can be treated with fluid restriction or with demeclocycline (though this is expensive) while a cause and definitive treatment are sought. This paper illustrates two important points: 1) extreme hyponatremia may develop with surprisingly few symptoms if it occurs over a prolonged period of time and 2) even very severe hyponatremia may be successfully corrected - though in this case, the patient had an associated disease process that was later fatal.

\section{Competing interests}

The authors declare that they have no competing interests.

\section{Authors' contributions}

Conception and design (mcp), data abstraction and analysis (both), writing initial draft (gvw), revision and editing (both), approval of final draft (both)

\section{Consent}

Our patient is deceased and thus unable to sign consent for this publication, but did sign consent to be treated during the hospitalization. All identifying information has been removed.

\section{References}

I. Adrogué HJ, Madias NE: Hyponatremia. N Engl J Med 2000, 342: $158 \mid-1589$.

2. Sørensen JB, Andersen MK, Hansen HH: Syndrome of inappropriate secretion of antidiuretic hormone (SIADH) in malignant disease. J Intern Med I995, 238(2):97-I I0.

3. Johnson BE, Chute JP, Rushin J, Williams J, Le PT, Venzon D, Richardson GE: A prospective study of patients with lung cancer and hyponatremia of malignancy. Am J Respir Crit Care Med 1997, I56(5): 1669-1678.

4. Kamoi K, Ebe T, Hasegawa A, Sato F, Takota H, Iwamoto H, Kaneko $\mathrm{H}$, Ishibashi $M$, Yamaji T: Hyponatremia in small cell lung cancer. Mechanisms not involving inappropriate ADH secretion. Cancer 1987, 60:1089-1093.

5. Sonnenblick M, Friedlander Y, Rosin AJ: Diuretic-induced severe hyponatremia. Review and analysis of $I 29$ reported patients. Chest 1993, I03(2):601-606.

6. Udy A, Deacy N, Barnes D, Sigston P: Tramadol-induced hyponatraemia following unicompartmental knee replacement surgery. Anaesthesia 2005, 60(8):814-8I6.

7. Hayashi $T$, Ishida $Y$, Miyashita T, Kiyokawa H, Kimura A, Kondo T: Fatal water intoxication in a schizophrenic patient - an autopsy case. J Clin Forensic Med 2005, I 2(3): I57-I59. 
8. lioshi M, Sakuragi T, Higa K, Hamada T: Severe hyponatremia during transurethral resection of prostate. Masui 2005, 54(4):4|4-4I7.

9. List AF, Hainsworth JD, Davis BW, Hande KR, Greco FA, Johnson $\mathrm{DH}$ : The syndrome of inappropriate secretion of antidiuretic hormone (SIADH) in small-cell lung cancer. J Clin Oncol I986, 4:II9I-II 98.

Publish with Bio Med Central and every scientist can read your work free of charge

"BioMed Central will be the most significant development for disseminating the results of biomedical research in our lifetime. " Sir Paul Nurse, Cancer Research UK

Your research papers will be:

- available free of charge to the entire biomedical community

- peer reviewed and published immediately upon acceptance

- cited in PubMed and archived on PubMed Central

- yours - you keep the copyright

Submit your manuscript here:

http://www.biomedcentral.com/info/publishing_adv.asp 